Revista Iberoamericana, Vol. LXXVIII, Núm. 240, Julio-Septiembre 2012, 539-554

\title{
ENSAYOS SOBRE LA LENGUA POÉTICA EN CUBA
}

\author{
POR \\ Graciela NÉLida SALto \\ Universidad Nacional de La Pampa
}

La lengua poética es un tópico frecuente en los ensayos que abordan problemas vinculados con la literatura y, en especial, con la poesía, en las últimas décadas del siglo veinte. Esta focalización temática no es ajena al ensayo cubano. Por el contrario, la pregunta por la lengua literaria puede identificarse en un extenso recorrido de textos que han interrogado los usos lingüísticos a la vez que dirimido espacios de representación poética y codificado diferentes tradiciones de escritura. Entre los ensayistas que comienzan a producir en la década de 1980, esta pregunta adquiere renovados matices y modalizaciones que ponen de manifiesto la vigencia del valor asignado a los usos de la lengua en las transformaciones literarias y culturales producidas en la isla en el último siglo, y el impulso a su discusión y resignificación promovidos por algunos de los nuevos ensayos del período.

En un espacio intelectual atravesado por crecientes tensiones, el coloquialismo o conversacionalismo, una de las matrices culturales pautadas en los primeros años revolucionarios, aparece todavía como la tendencia poética dominante. Con firme arraigo en los temas y en las retóricas privilegiadas por la praxis heroica, el tono coloquial es reconocido por los críticos como la norma de lo decible hasta avanzada la década de 1980. En relación y articulación con este registro han ido emergiendo, sin embargo, otras prácticas poéticas que, con diferentes niveles de formalización y difusión, pugnan por alcanzar cierto grado de inteligibilidad. Son configuraciones que, desde diversas variantes del culturalismo hasta experimentos neovanguardistas, produjeron deslizamientos, desvíos y discusiones de lo coloquial de modo tal que, hacia fines de este período e inicios de 1990, varios críticos comienzan a hablar de "postconversacionalismo" (Arcos XLI; Dorta Sánchez 24; Morejón Arnaiz 36) para identificar una serie heteróclita de prácticas que, a pesar de sus múltiples diferencias, confluyen en cierto afán por discutir el imaginario poético revolucionario vinculado, prioritariamente, con lo conversacional.

Este énfasis en la discusión de un registro de la lengua ha sido señalado, en efecto, como una de las características más relevantes del período, incluso desde diferentes posturas teóricas y críticas. Osmar Sánchez Aguilera habla de la "reserva ética-estética 
hacia las palabras” en la generación poética de los ochenta (Poesía en claro 53); Damaris Calderón, de la "desconfianza hacia la palabra" ("Virgilio Piñera”); José Kozer, de un "problema de palabras" ("Martí” 63); Víctor Fowler, de "cansancio de la lengua transparente" (Tarea 12), entre varios otros ensayistas que también encuentran en las nuevas actitudes ante la lengua una de las marcas de la innovación poética. Si bien algunos de ellos señalan que sólo se estaría produciendo una reconversión dentro del coloquialismo mismo que no implicaría un corte diferencial respecto de la norma conversacional (Dorta Sánchez 30), otros postulan, en cambio, que se estaría en presencia de una "ruptura radical” en la lengua poética contemporánea (Fowler, Tarea 15) y muchos otros no indagan el problema en términos de continuidad o de ruptura, sino que ponderan sus posibilidades innovadoras en el marco de una relectura de la tradición literaria y cultural que, a partir del proceso revolucionario, exacerbó sus rasgos normativizadores (Díaz, "De la casa” y Límites; Fornet; Rojas). La mayoría acuerda, sin embargo, en el peculiar valor performativo de "la desconfianza hacia la palabra" que, tal como reconoce Dorta Sánchez (27) en un estudio reciente, ha adquirido ya el estatuto de tópico en los ensayos metacríticos de los últimos años.

Por esta razón, y sin desconocer la existencia de otras problemáticas que también se hacen legibles en los ensayos de la época (Fowler, "Ensayismo”; Díaz, Límites; Fornet; Basile), en este artículo se analizan dos modulaciones de este tópico en el espacio cultural cubano. En primer lugar, la valoración de la oralidad cotidiana y barrial en relación irónica con el alcance de los prosaísmos del lenguaje revolucionario. En segundo lugar, la renovada indagación en torno de los elementos del choteo articulados ahora con rasgos del barroco, como la burla y la risa, que se creían postergados por la plenitud significante de esta misma poética en su versión origenista. Se parte de varias hipótesis articuladas. ${ }^{1}$ Por un lado, estas modulaciones implican actitudes que, en estrecha combinación entre sí, condensan, aunque no agotan, algunas de las resignificaciones más innovadoras de la lengua poética. Por otra, discuten la confianza en el valor referencial del lenguaje, identificado como una estrategia glotopolítica de la revolución, y proponen a la vez la polisemia de otros usos lingüísticos llamados a veces relajados; otras veces, confusos, sucios, intrascendentes o proliferantes. La mayoría de ellas permite leer desde el presente las fisuras de una tradición literaria que, desde mediados del siglo diecinueve, fue obliterando o clasificando como desvíos, intrascendencias o residuos, la heterogénea pluralidad de voces y de tonos discordantes, y busca recolocarlos en un lugar prominente de articulación cultural. En la primera parte de la exposición, se

1 Algunas hipótesis iniciales fueron presentadas en el II Congreso Internacional Celehis de Literatura Latinoamericana/Argentina/Española celebrado en Mar del Plata, Argentina, del 25 al 27 de noviembre de 2004 y en las XVIII Jornadas de Investigación de la Facultad de Ciencias Humanas, Santa Rosa, Argentina, 6 al 8 de setiembre de 2007.

Revista Iberoamericana, Vol. LXXVIII, Núm. 240, Julio-Septiembre 2012, 539-554
ISSN 0034-9631 (Impreso) 2154-4794 (Electrónico) 
revisarán someramente algunos hitos de esta tradición y, en la segunda, se analizarán rasgos del tópico que, en los últimos años, está cuestionando y disgregando desde el ensayo la unicidad simbólica de la lengua poética cubana.

\section{OTRO LENGUAJE RELAJADO Y CONFUSO}

La hipótesis sobre la existencia de una lengua única se remonta a los intentos de registrar la peculiaridad americana, promovidos por los grupos ilustrados en los años inmediatamente posteriores a la proclamación de las independencias. Si bien Cuba no logró alcanzar su liberación a inicios del siglo diecinueve, su círculo letrado compartió el clima de ideas, lecturas y propuestas americanistas que se había expandido por la mayoría de los centros urbanos del continente. ${ }^{2}$ De hecho, el primer léxico americano conservado hasta hoy surgió en Cuba: el Diccionario provincial casi razonado de vozes y frases cubanas editado en 1836 por Esteban Pichardo Tapia. ${ }^{3}$ Aunque esta recopilación tuvo, como otras del mismo período, la mera intención de identificar usos que se apartaban de la norma, ya pueden advertirse en él las dificultades que surgían de la propensión ilustrada hacia una lengua ideal, armonizadora de las diferencias, y la constatación inocultable de la variación. "Otro lenguaje relajado y confuso se oye diariamente en toda la Isla”, dice Pichardo en el prólogo (IV). La sola mención de esta diferencia entre la lengua buscada y la oralidad cotidiana pone de manifiesto las dificultades que enfrentaban estos letrados para transfigurar la heterogeneidad lingüística en la imagen unificadora de una lengua nacional, tal el acicate del Romanticismo ilustrado. Varias décadas después, el problema habría de adquirir otras connotaciones en un período de auge del ensayo en Cuba. Desde la perspectiva antropológica y folklórica que signó la discusión sobre lo nacional en el período republicano, ${ }^{4}$ Fernando Ortiz reconocería su deuda con la temprana compilación de Pichardo en el conocido léxico que tituló Catauro de cubanismos (1923) y planteará en su prólogo la necesidad política de dar cabida a esos otros registros detectados por

2 Estudios recientes como el de Aguilera Manzano o el de González-Ripoll están documentando el entramado de lecturas de la Ilustración que conecta a los letrados cubanos con los de otras áreas continentales en el mismo período. Por otra parte, la creciente tendencia historiográfica que enfatiza la participación popular en las insurrecciones que dieron origen a las independencias, también está produciendo aportes interesantes para el caso cubano, como el de Blanchard.

3 Habrían existido otros antecedentes no conservados. "El primer documento donde consta la preocupación por el estudio del léxico 'provincial' aparece en las Memorias de la Real Sociedad Patriótica de La Habana, con fecha 29 de octubre de 1795 [...] Más tarde, hacia 1831, Domingo del Monte trabajó junto con Francisco Ruiz, José Estévez, Joaquín Santos Suárez y José del Castillo en un diccionario de provincialismos cubanos, obra que quedó inconclusa e inédita” (Ortiz 11).

4 Un caudal creciente de investigaciones está analizando el entrecruzamiento de antropología y nacionalismo en las primeras décadas del siglo veinte (Naranjo Orovio; Ortiz García). Sobre la profusión de ensayos en este período, véase Rojas 217-47.

\footnotetext{
Revista Iberoamericana, Vol. LXXVIII, Núm. 240, Julio-Septiembre 2012, 539-554 ISSN 0034-9631 (Impreso) 
su antecesor. ${ }^{5}$ Para entonces, la conveniencia de legitimar los usos populares o vulgares había sido objeto de varios contrapuntos que, incluso desde ópticas discordantes, fueron formando una tradición de análisis de la oralidad y de la coloquialidad como marcas de lo cubano. ${ }^{6}$ En este itinerario sobresalen las estrategias de José Martí quien, con una aguda percepción de las fracturas que la desterritorialización infligía a la norma heredada, había logrado a fines del siglo diecinueve la imbricación poética de registros del habla cotidiana y afectiva con los matices y contrastes aportados por la modernización en ciernes (Contardi; Ramos; Zanetti). Fue entonces cuando algunos tonos y ritmos de aquel "lenguaje relajado y confuso" adquirieron rango poético moderno, pudieron ser recuperados en tanto materiales de experimentación y análisis por los movimientos africanistas y regionalistas de las décadas siguientes y llegaron a condensarse, a fines del veinte, en torno de la imagen de la idiosincrasia popular. Aunque en la Indagación del choteo (1928) Jorge Mañach no analiza explícitamente la impronta lingüística de la tendencia hacia la ironía, la burla y el menudeo desjerarquizadores que encuentra en su célebre ensayo sobre lo cubano, la idea de que este gesto o actitud está en estrecha vinculación con ciertos usos del lenguaje es, desde entonces, una percepción extendida hasta hoy, cuando algunos ensayistas encuentran en él un anclaje para la deconstrucción de la seriedad y la parsimonia que detectan en la lengua estandarizada a partir de la década del sesenta.

Si bien el gobierno revolucionario no precisó un mandato estilístico ni tampoco lingüístico para la escritura, los debates suscitados desde el inicio pusieron en el centro del debate el problema de la lengua literaria. En 1959 se fundó el Instituto Cubano del Arte y la Industria Cinematográfica (ICAIC), la Imprenta Nacional de Cuba y otras instituciones culturales, promovidas y sostenidas por el Estado. Pero, es a mediados de 1961 cuando este proceso de integración y unificación de las organizaciones políticas y culturales tuvo su correlato literario con la creación de la Unión de Escritores y Artistas de Cuba(UNEAC) y la consecuente multiplicación de polémicas en torno de la literatura.

\footnotetext{
5 "Cuba tiene el lenguaje sucio de su mala vida, como todos los pueblos. Ignorarlo no es obra de civismo, sino sencillamente, una ignorancia, ésa sí que es una claudicación pueril de elementales deberes públicos" (Ortiz 19). La relevancia del léxico de Ortiz ha sido actualizada en los últimos años. Por ejemplo: "Un buen punto de partida, para reconstruir el proceso cultural de la Revolución cubana, sería el glosario de nociones claras y distintas del habla política. Un catauro, que aunque sólo sea el compendio de voces de una persona, sirva, al menos, para hacer más fluída la comunicación intelectual” (Rojas 36).

6 Las implicaciones ideológicas de categorizar la lengua como popular o vulgar fueron analizadas por Pierre Bourdieu y, en una línea coincidente, la revista Marges linguistiques publicó en 2003 un volumen conjunto sobre éstas y otras representaciones denigratorias de la variación lingüística (<http://www. marges-linguistiques.com>) que, en los últimos años, están siendo discutidas además en el marco de los estudios sobre ideologías de las lenguas (véase Language Ideologies, de Schieffelin, Woolard y Kroskrity).
}

\footnotetext{
Revista Iberoamericana, Vol. LXXVIII, Núm. 240, Julio-Septiembre 2012, 539-554 ISSN 0034-9631 (Impreso) ISSN 2154-4794 (Electrónico)
} 
La prédica a favor de las prácticas miméticas logró ocultar rápidamente el legado de vanguardia de la Revista de Avance (1927-1930), la estética insular de Orígenes (1944-1956) y la rebeldía existencial de Ciclón (1955-1959), a la vez que entronizó una literatura ligada, desde la temática hasta los lexemas, a la unidad revolucionaria. Se discutió la experimentación y se ponderaron, en varias oportunidades, sólo las obras que seguían los principios del realismo social. La innovación quedó así restringida y las creaciones poéticas centradas en el lenguaje ${ }^{7}$ se desvincularon de una literatura que intentaba responder a un "sentido teleológico de la historia, una escritura obligada a girar alrededor de un núcleo fundacional” llamado José Martí (Fowler, “Tarea” 14) en quien se sobredimensionó la heroicidad patriótica en detrimento de su legado más moderno. ${ }^{8}$ También se monumentalizó la obra de otros poetas que habían sido convertidos en íconos culturales: Nicolás Guillén, Cintio Vitier o, más tarde, José Lezama Lima, entre algunos de los más visibles. ${ }^{9}$

Como consecuencia, y a pesar de que la legitimación de ciertos usos basados en la ilusión de un idioma estándar nacional fue subvertida siempre por la irrupción de otros registros, voces y modos, la imagen de una comunidad político-lingüístico-cultural logró afianzarse en las décadas posteriores a la proclamación del gobierno revolucionario. Por esta razón, no es extraño que en 1971 Roberto Fernández Retamar pueda iniciar su ensayo Calibán con una pregunta que da por sentada la existencia de una única lengua: "Ahora mismo, que estamos discutiendo [...] con esos colonizadores ¿de qué otra manera puedo hacerlo sino en una de sus lenguas, que es ya también nuestra lengua...? (Calibán 16). ${ }^{10}$ La aporía introduce, como es sabido, uno de los ensayos de mayor repercusión

7 "Se atacó in toto a la nueva narrativa latinoamericana. Era natural que la emergencia de un discurso teórico [...] que en rasgos muy someros afirmaba que en literatura lo único importante era el lenguaje, resultara [...] particularmente irritante para la fracción 'revolucionaria' del campo intelectual” (Gilman 332-33). No obstante, en 1981 ya se advierten ciertas actitudes reparadoras del rechazo inicial (Díaz, Límites 223-24).

8 En este sentido, José Kozer afirma, por ejemplo, que "es imposible vivir con el lenguaje y la pureza ética del Apóstol” [José Martí]. (64). José Antonio Ponte agrega que: “Para soportar a Martí es preciso destruirlo, hay que reírse de él, burlarse, tirarlo a choteo [...] sacarlo del museo de las santas escrituras muertas e hincarle el pie por todos los flancos" ("Lengua” 120-21). La recepción contemporánea de la obra de Martí también fue analizada por Bernabé y por Rojas, entre otros.

9 Véase, por ejemplo, la negación de los poetas de Orígenes en Sánchez Mejías (1994): "Era un tiempo de los orígenes donde todos nos sabíamos de vuelta por el poder de las palabras [...] Un buen día uno comprende que las palabras no son tan poderosas como para emprender el camino de vuelta [...] entonces uno comienza a borrar sus propias huellas, y cuando termina, hace mutis por el foro". El proceso general de discusión de los poetas de Orígenes fue abordado también por Calomarde y, más recientemente, por Basile.

${ }^{10}$ La primera versión aparece en un artículo publicado por Casa de las Américas en 1969. Una década después, el autor mismo se encarga de comentar el contexto de producción de este ensayo y algunas de sus derivaciones (Fernández Retamar, “Calibán revisitado”). Para entonces, el ensayo había logrado transformar a la figura de Calibán en una de las claves de indagación de lo latinoamericano (Weinberg; Jáuregui).

Revista Iberoamericana, Vol. LXXVIII, Núm. 240, Julio-Septiembre 2012, $539-554$
ISSN 0034-9631 (Impreso) 
en el período revolucionario ya que celebra la potencialidad de la voz del esclavo para subvertir el monolingüismo del amo. Sin embargo, esta torsión del arielismo que, desde fines del siglo diecinueve había recuperado la figura shakesperiana para representar el conflicto colonial, hace caso omiso de los ideologemas también coloniales que omiten la variación lingüística, jerarquizan entre lenguas y dialectos, y unifican sus especulaciones en torno de una única variedad considerada estándar. La pregunta de Retamar no parte de la pluralidad de las lenguas ni de los lenguajes hablados y escritos en Cuba, sino de la existencia de una sola lengua que pone en disputa. ${ }^{11}$ Dos décadas después esta actitud monolingüe puede reconocerse todavía en los escritos de algunos intelectuales vinculados con el Estado. En el primer número de La Gaceta de Cuba, correspondiente a los meses de enero y marzo de 1999, Rafael Hernández, uno de los más prominentes miembros de la inteligencia revolucionaria, publicó un artículo titulado "Sobre el discurso", donde afirma que "sería excesivo postular una relación desmesurada entre las más diversas formas de transgresión verbal tan abundantes en el habla popular y la expresión de disrupciones en el orden de valores o patrones ideológicos dominantes” (175). Es posible advertir en su argumento la escasa variabilidad de la matriz de análisis que, en el siglo diecinueve comenzó a distinguir entre una lengua cubana, "nuestra lengua” en palabras de Fernández Retamar, y esta otra, llamada aquí popular; antes, confusa y relajada, más tarde, sucia. La lengua es casi siempre transgresora y, en cuanto tal, tópico privilegiado de los ensayos que intentan resignificar, en los últimos tiempos, los núcleos fundacionales de la cubanidad.

EL SECRETEO Y EL GRITO DEL SOLAR

Este sinuoso aunque somero rastreo de algunas huellas de la pluralidad lingüística, apenas vislumbradas tras la imagen monolingüe, explica, en cierta medida, que cuando comienza a resquebrajarse la comunidad literaria erigida a partir de lo heroico, de lo mitológico y de lo paradisíaco, la lengua reaparece como uno de los nodos de mayor densidad significativa. En la medida en que los acontecimientos políticos y económicos de fines de los ochenta agudizaron el análisis y la revisión de las matrices culturales estatuidas, ${ }^{12}$ su unicidad comenzó a ser leída como superficie de emergencia simbólica de antiguos y disímiles procesos de homogeneización, ahora más visibles, tanto en la formalización conversacional promovida por la mayoría de los intelectuales

${ }^{11}$ Las implicaciones ideológicas de esta omisión exceden los alcances de este artículo, no obstante deberían ser analizadas a partir de los estudios fundadores de Louis-Jean Calvet en la década del setenta y de la productiva corriente analítica en torno del colonialismo lingüístico desarrollada en las últimas décadas (Errington).

12 Los cambios sociales y económicos producidos en las últimas décadas están siendo objeto de múltiples acercamientos. Para un estado de la cuestión desde el punto de vista sociológico, véase Bobes.

\footnotetext{
Revista Iberoamericana, Vol. LXXVIII, Núm. 240, Julio-Septiembre 2012, 539-554 ISSN 0034-9631 (Impreso) ISSN 2154-4794 (Electrónico)
} 
revolucionarios como en otras modelizaciones, entre las que ocupa un lugar destacado la de los escritores que habían confluido en torno de la revista Orígenes, leídos y debatidos, con énfasis, a partir de 1980.

En los inicios de estos años, es posible datar una primera etapa de reconocimiento del origenismo como una poética liberadora de la norma conversacional. En la audacia combinatoria de las múltiples imágenes, figuras y lexías de José Lezama Lima, sobre todo, los jóvenes ensayistas y poetas de la época avizoran una apertura en el horizonte de la referencialidad coloquial. La lengua de Lezama les ofrece un vocabulario, una sintaxis e incluso una morfología que traspasan el horizonte de la comunidad lingüística y exploran los límites de lo decible. ${ }^{13}$ Sin embargo, una segunda etapa de muy distinto signo sobreviene a fines de esa misma década. En forma paralela al proceso de institucionalización de algunas figuras nucleadas alrededor de Orígenes, en especial la de Lezama (Hernández Busto, "Lezama”; Díaz, Límites; Morán 57), se produce una notoria discusión de sus lineamientos poéticos, ya que se les comienza a endilgar la postulación de una imagen mitopoiética de la realidad y el hecho de que esta configuración haya confluido, si no políticamente, sí con algunas matrices simbólicas del período revolucionario. ${ }^{14}$ Varios acontecimientos discursivos, académicos y editoriales delinean los vericuetos de esta discusión. En 1987 aparecen, entre los documentos publicados en el primer número de la revista Diáspora(s), dos textos muy leídos entre algunos de los nuevos poetas: “Olvidar Orígenes”, de Rolando Sánchez Mejías, y “Orígenes y los ochenta”, de Pedro Marqués de Armas. En 1992, Marcelo Uribe publica en México la esperada edición facsimilar de la revista y, en el mismo año, se realiza en La Habana el Coloquio Piñera donde un joven José Antonio Ponte lee "La lengua de Virgilio”, uno de los textos que

${ }^{13}$ En La expresión americana, por ejemplo, Lezama Lima establece un reconocimiento del valor poético de las otras voces y matices que conforman también lo criollo: "cuando el lenguaje [europeo] decae, [los americanos] ofrecemos la dionisíaca guitarra de Aniceto el Gallo” (Lezama Lima, Expresión 441). Sobre la contribución de José Lezama Lima a la percepción de la hibridez como marcador de la cultura americana, véase Salgado.

${ }^{14}$ Dice Damaris Calderón (“Virgilio Piñera”): "Se ha insistido hasta la saciedad en la influencia de José Lezama Lima (figura cimera y aglutinadora) en nuestra literatura, entre sus coetáneos y las generaciones posteriores, así como la influencia de Eliseo Diego en las jóvenes promociones a partir de un lenguaje coloquial, que se alejaba del hermetismo inicial origenista y buscaba el pequeño suceso, la anécdota, el detalle nimio, para dotarlo de una trascendencia y un carácter de fábula. Así, de una escritura que alcanzaba hidalguía estética y ética, que aunaba la raíz patria y lo foráneo con encomiable ecumenismo, puede decirse que, en la literatura cubana, de nada se nutre tanto la generación de los ochenta como de lo aportado por el grupo Orígenes”. Otras intervenciones han analizado más específicamente las diferentes propuestas estéticas e ideológicas que coexistieron bajo el nombre de Orígenes y su articulación con el proceso revolucionario (Uribe; Fernández Retamar, “Orígenes”; Ponte, El libro; Díaz, Los límites). Adriana Kanzepolsky (197-98) señaló, por ejemplo, cómo varios de los textos de autores extranjeros publicados en esta revista abordaban cuál debía de ser la función de la lengua poética en tiempos de guerra y anticipaban, sin saberlo, debates que se darían en Cuba en las décadas siguientes.

Revista Iberoamericana, Vol. LXXVIII, Núm. 240, Julio-Septiembre 2012, $539-554$
ISSN 0034-9631 (Impreso) 
incluirá una década después en el conocido volumen de ensayos El libro perdido de los origenistas (2002). En 1994, Casa de las Américas organiza también un Coloquio titulado Orígenes y su influencia en los nuevos escritores; en 1997, Fina García Marruz da a conocer La familia de Orígenes y, en 2005, Duanel Díaz publica Límites del origenismo. Son estos algunos de los más conocidos y polémicos episodios de reconocimiento y procesamiento crítico del legado de la revista. De este intrincado y complejo proceso de recepción, interesa destacar aquí que uno de los núcleos condensadores de las múltiples y dispares lecturas que se hacen en esta época es la indagación en torno de los usos origenistas de la lengua.

El barroquismo hermético de Lezama ofrece primero un campo de exploración para oponer a los límites referenciales del coloquialismo, pero avanzada la década de 1990 se lee con avidez la nimiedad, la intrascendencia, el cinismo y la ironía de "La lengua de Virgilio”. Plantea allí, a partir de una escena de pugilato, a la necesidad de reconfigurar una tradición literaria que lo "cansa”, lo "aburre” y lo "fastidia”. Desde estas causas, más emotivas que estéticas, presenta en 1992 en el Lyceum de La Habana un texto que discute el famoso curso dictado allí mismo por Cintio Vitier entre octubre y diciembre de 1957 y conocido como Lo cubano en la poesía. El Lyceum se transforma así en el escenario de la disputa por la tradición. ${ }^{15}$ Ponte hilvana algunos episodios del siempre aludido y poco documentado antagonismo entre Lezama y Piñera para concluir en la exaltación de la posición antagónica del último. Ante la plenitud de las figuras patriarcales -Lezama y Martí, en las hipótesis de Vitier- Ponte opone la marginalidad de quien escribe para reponer la falta y en esta reposición lega un archivo que se actualiza en el fin de siglo:

[Piñera] nos legó un repertorio de frases que decir en los ómnibus o en las paradas por donde éstos no pasan, en las casas de huéspedes y en el bar, en la esquina y en el patio de butacas, en la antesala del dentista y en la funeraria, en el parque y en la carnicería, en la barbería y en la cola del pan, en la crónica social y en la policíaca, en el secreteo y en el grito del solar. (“Lengua” 52)

Es decir, un nuevo repertorio léxico que es también poético, sin trascendencia oficial ni gubernamental, voces "menores" que disuelven el sueño origenista de la isla, la unidad teleológica de Lezama, en un "archipiélago” de palabras, en una "muchedumbre” de vocablos, en una antillanización de la literatura. "Cuba se ha convertido, Piñera mediante, en una Antilla cualquiera, nos antillanizamos”, dice Ponte ("Lengua” 48). ${ }^{16}$

${ }^{15}$ La contribución de Antonio José Ponte a la revisión de la tradición literaria y cultural cubana excede los objetivos de este artículo. No obstante, pueden verse los estudios compilados por Teresa Basile.

${ }^{16}$ Las implicaciones ideológicas del imaginario geopolítico cubano han sido analizadas por Ette ("Literatura sin fronteras" y "Literatura sin residencia”).

\footnotetext{
Revista Iberoamericana, Vol. LXXVIII, Núm. 240, Julio-Septiembre 2012, 539-554 ISSN 0034-9631 (Impreso) ISSN 2154-4794 (Electrónico)
} 
En el paso de la isla al archipiélago, de la unidad a la polisemia, de la homogeneidad a la proliferación, la "lengua fría" de Piñera, sus pesadillas, comienzan a ocupar el espacio enunciativo dejado por el sueño incumplido de Orígenes: “[...] pesadillas que no asustan tanto desde que podemos saltar gritando en el anagnórisis: 'Si esto es Virgilio puro, caballeros'. [...] Como personajes suyos hablamos en Piñera clásico, hemos caído en la lengua de Virgilio” (Ponte, "Lengua” 51-52). Esta “caída en la lengua de Virgilio" invierte el símil tradicional de la anagnórisis y mediante varias connotaciones intertextuales corroe la imagen de la lengua única en pos de la legitimación de otros usos que han devenido "clásicos": los del secreteo y los del grito del solar. ${ }^{17} \mathrm{El}$ anclaje en el habla y en el decir comunes, opuestos al lenguaje de la ciudad-estado, no era privativo, sin embargo, de las pesadillas de Piñera, puesto que pueden identificarse rasgos y gestos de estos otros decires, en otros textos que han experimentado también con la oralidad y con el borramiento de los límites de la norma estándar. ${ }^{18}$ Sin embargo, las vicisitudes y tensiones del espacio intelectual cubano colocaron a Orígenes como el agonista principal de las últimas décadas. Desde allí se leen los estertores del lenguaje referencial y algunos ensayistas, como Ponte, encuentran a su vez en las pesadillas de uno de sus miembros la posibilidad de rearticular un programa poético a partir de los fragmentos de la lengua única, de su antillanización, de sus residuos.

\section{LA COLORIDA URDIMBRE DEL LENGUAJE COTIDIANO}

La lengua poética de Lezama no quedará relegada, sin embargo, ante esta valoración de la "lengua clásica” de Piñera. Una década después, su lectura acaba de renovarse con un sesgo inesperado. El 23 de junio de 2006, Margarita Mateo Palmer leyó su discurso de ingreso en la Academia Cubana de la Lengua: "Las palabras como peces dentro de la cascada: Lezama Lima y el lenguaje”, un ensayo sobre los usos de lo popular en la lengua de Lezama. La revista Casa de las Américas, un conocido árbitro intelectual, lo reprodujo inmediatamente. También La Jiribilla en su edición virtual. Con un epígrafe de Severo Sarduy sobre el padecimiento y la agonía que conlleva "heredar a Lezama", el texto se inserta en la peculiar contienda surgida a partir de la lectura de la lengua de Orígenes. En la "resistencia de la obra de José Lezama Lima al paso del tiempo", Mateo Palmer ubica la necesidad de reivindicar la "figura del gran intelectual cubano" de las burlas, los chistes y otras ridiculizaciones centradas en sus usos de la lengua.

17 Pocos años más tarde, Alberto Garrandés modaliza apenas esta cita de Ponte sobre el lugar preponderante de lo coloquial, del susurro, del secreteo, en la configuración de lo cubano: “[...] la Habana vuelve a ser por momentos, instantes comprometidos con el habla y el decir comunes -comentarios, suposiciones, cotilleos...” (28).

18 Entre otros, sobresalen novelas como Tres tristes tigres (1964), de Guillermo Cabrera Infante, uno de los nodos de mayor experimentación lingüística en las décadas anteriores.

\footnotetext{
Revista Iberoamericana, Vol. LXXVIII, Núm. 240, Julio-Septiembre 2012, 539-554 ISSN 0034-9631 (Impreso) 
Donde otros críticos y ensayistas detectaron errores ortográficos, incorrecciones, erratas, falsos neologismos, anomalías sintácticas, etc., Mateo Palmer advierte un juego de apropiaciones transculturales que, por un lado, logran ubicar a Lezama en el lugar de precursor de las actuales teorías sobre la intertextualidad y la interdiscursividad y, por otro, catapultarlo como un intelectual particularmente atento a los usos populares de la lengua. Varias estrategias confluyen en esta operación legitimadora de lo popular en Lezama. Por un lado, las consabidas citas de autoridad, en este caso, sobresale la de Fernández Retamar, quien dice recordar que Lezama le habló del carnaval como forma de apropiación y burla de lo señorial antes de la difusión de la obra de Mijail Bajtin. Por otro, la vinculación del gesto carnavalesco con el choteo "no en su sentido peyorativo, -aclara Mateo Palmer- sino en su violación jocunda de toda autoridad, su recusamiento de lo establecido, su burla a las jerarquías, su carácter transgresor de lo normativo". Por otro, la vinculación de ambos gestos con una visión de lo popular anclada en el gozoso devenir de la lengua cotidiana:

No es de extrañar que un creador con la extraordinaria sensibilidad lingüística de Lezama hubiese estado muy atento a las fluencias y giros del habla popular. Su escritura se nutría de los hallazgos de una lengua viva, en constante transformación y movimiento. En la colorida urdimbre del lenguaje cotidiano hallaba una fuente de apropiaciones libérrimas y gozosas de las palabras. (versión en internet)

Se establece así una triple implicación entre carnaval, gozo y lengua cotidiana que, con resabios de neta inspiración romántica, articula el "organismo vivo de la lengua” del pueblo con la representación barroca de Lezama. Donde se leyó opacidad referencial, anomalías e incongruencias sintácticas, oscurantismo e impostura barrocas, Mateo Palmer encuentra "la colorida urdimbre del lenguaje cotidiano". En su celebrado ensayo Ella escribía poscrítica (1995), ${ }^{19}$ ya había postulado que el lenguaje del choteo es una de las "características dominantes de la cultura cubana vinculadas con el exceso verbal y el abigarramiento ornamental e impetuoso del lenguaje” (92). En su actualización crítica del clásico estudio de Mañach, vinculó este gesto con el neobarroco, con la transculturación y con el carnaval, tres conceptos que, como ella misma reconoce, provienen de distintas esferas aunque conectadas por una estrategia característica de la posmodernidad literaria: la intertextualidad. Desde allí, desde el intertexto, traza un linaje de usos lingüísticos que, reconocidos ya por Fernando Ortiz, habrían configurado una "tradición descanonizadora" (91) en la lengua cubana.

Esta actitud choteadora implicaría a un mismo tiempo un gesto liberador en el ámbito literario, que ejemplifica con textos de Piñera y ahora también de Lezama. De

${ }^{19}$ El ensayo recibió el Premio “Razón de ser” de la Fundación Alejo Carpentier. Para los alcances de su recepción crítica, véase de Toro.

Revista Iberoamericana, Vol. LXXVIII, Núm. 240, Julio-Septiembre 2012, $539-554$
ISSN 0034-9631 (Impreso) 
hecho, en varios ensayos de los últimos años (García Borrero), la confusión, el relajo, la suciedad y esta versión peculiar del choteo forman un haz de rasgos atribuidos con distinta intensidad y gradación a la lengua poética (Rodríguez Gutiérrez; Salto). De este modo, se advierte una modulación del registro lingüístico que, durante décadas, fue legitimado por los usos oficiales y escolares y también por los vates encumbrados a la categoría de nacionales a partir del período revolucionario. Se observa la recuperación de un linaje alternativo de ideas sobre el "otro lenguaje”, tanto desde algunos canales de difusión institucional como de ciertas redes y núcleos de circulación cultural externos, muchos de ellos ubicados en la isla misma, desde donde se intenta confrontar "las hablas y las lenguas políticas”, como lo ha descrito incisivamente Rafael Rojas en Motivos de Anteo. ${ }^{20}$

\section{CONCLUSIONES}

Después de varias décadas de auge e impregnación referencial de muchas de las prácticas culturales que caracterizaron el período revolucionario, a fines de la década de 1980 comienzan a explorarse otros registros y posibilidades de la lengua que horadan tanto esta ilusión conversacional como el monolingüismo que articuló, con escasos desvíos, su imaginario poético. La "desconfianza hacia la palabra” se convierte así en un tópico de ensayos que, desde perspectivas disímiles e incluso contradictorias, analizan y discuten los alcances poéticos de la norma conversacional y, a partir de ella, delinean otras opciones que van desde estilizaciones del mismo coloquialismo hasta relecturas transculturadoras del choteo, una de las marcas de la coloquialidad cubana. En este artículo se abordaron dos modulaciones de este tópico. Por un lado, la desconfianza hacia la grandilocuencia, hacia las voces trascendentes de Lezama y de Martí, que hace posible la creciente legitimación poética de los usos coloquiales de Virgilio Piñera. Estos usos configuran, en la formulación ensayística de Antonio José Ponte (1992), un legado de palabras nimias, las del secreteo y las del grito del solar, aptas para contrarrestar el vacío y el hueco generado por las ruinas monumentales del origenismo. Por otro lado, se abordó la desconfianza hacia las palabras sin sentido social, hacia los meros juegos de palabras, hacia el choteo. Esta desconfianza hace posible, según la tesis de uno de los últimos ensayos de Margarita Mateo Palmer, la

${ }^{20}$ El objetivo de Motivos de Anteo. Patria y nación en la historia intelectual de Cuba, el ensayo de Rafael Rojas publicado en 2008, es el análisis del proceso cultural de la Revolución cubana a partir de la deconstrucción analítica de "las hablas y las lenguas políticas" (sic) que, desde los primeros tiempos coloniales, fueron configurando el imaginario de la nación: "El habla cubana ha recorrido casi todas las lenguas políticas [...] de la modernidad. En la Colonia predominaron las hablas liberales y conservadoras, en la República las socialdemócratas y republicanas y en la Revolución ha prevalecido el habla 'socialista'. El predominio de un habla sobre otra, en cada época, se logra por medio de mecanismos de imposición y distribución del poder y del saber” (Rojas 34-35).

\footnotetext{
Revista Iberoamericana, Vol. LXXVIII, Núm. 240, Julio-Septiembre 2012, 539-554 ISSN 0034-9631 (Impreso) 
revalidación de los usos desviados, sesgados y barrocos de Lezama, como si fueran meras apropiaciones, aunque carnavalescas y transculturadoras, de fuentes atesoradas en una hipotética lengua cotidiana. En uno y otro caso, la discusión no aparece centrada en la prevalencia poética de lo conversacional, sino en los modelos que definirían sus rasgos de acuerdo con tradiciones que son compulsadas entre las diferentes propuestas poéticas que nucleó la revista Orígenes y, en los dos casos, además, pueden reconocerse sus antecedentes en una intrincada red de ensayos sobre la lengua y la cultura cubanas. Por último, no son las únicas y quizá tampoco las más relevantes modulaciones que pueden detectarse en torno de la "desconfianza hacia la palabra”, pero sirven como ejemplos de una tendencia contemporánea a la disección de la teleología insular y también de la revolucionaria que bucea en los restos y en los residuos de la lengua única. Sobre ésta se habían construido algunas de las imágenes más potentes de la unidad nacional que comienzan a ser revisadas a fines del siglo veinte y el ensayo aparece, tal vez por su carácter eminentemente friccional (Ette, "Literatura sin fronteras"; "Literatura sin residencia”), como un género apropiado para este proceso evaluativo. ${ }^{21}$

\section{BiBLIOGRAFÍA}

Aguiar Díaz, Jorge Alberto. “Preliminar”. Cacharro(s) 1. Julio-agosto 2003. < http:// revistacacharros.blogspot.com/>. 10 enero 2009.

Aguilera Manzano, José María. "Publicaciones periódicas e imprentas en La Habana ente 1824 y 1845 en los archivos cubanos y españoles”. Anuario de Estudios Americanos 64/1 (2007): 293-328.

Arcos, Jorge Luis, comp. "Las palabras son islas. Introducción a la poesía cubana del siglo XX”. Las palabras son islas. Panorama de la poesía cubana del siglo XX. La Habana: Letras Cubanas, 1999. XXXIV-XXXIX.

Basile, Teresa, comp. “Interiores de una isla en fuga. El ‘ensayo’ en Antonio José Ponte”. La vigilia cubana. Sobre Antonio José Ponte. Rosario: Beatriz Viterbo, 2009. 163-248.

Bernabé, Mónica. “Martí en la familia de Orígenes”. Legados de José Martí en la crítica latinoamericana. Susana Zanetti, comp. La Plata: Universidad Nacional de La Plata, 1999. 191-202.

${ }^{21}$ Es notoria la voluntad de organizar compilaciones de ensayos que actúen performativamente sobre la situación cubana y las polémicas que se suscitan ante cada una de esas publicaciones. Véanse, por ejemplo, De la Nuez (2001), Cuba y el día después, la antología de Ubieta Gómez, Vivir y pen(s)ar en Cuba (2002), y la respuesta contenciosa del mismo antólogo ese mismo año; la voluminosa antología de Hernández y Rojas (2002) y la polémica que desató, condensada en el artículo de Hernández Busto (2003), entre otras intervenciones.

Revista Iberoamericana, Vol. LXXVIII, Núm. 240, Julio-Septiembre 2012, $539-554$
ISSN 0034-9631 (Impreso) 
Blanchard, Peter. “The Language of Liberation: Slave Voices in the Wars of Independence.” Hispanic American Historical Review 82/3 (2002): 499-523.

Bobes, Velia Cecilia. "Complejidad y sociedad: cambios de identidad y surgimiento de nuevos actores en la sociedad cubana hacia el fin de milenio”. Estudios sociológicos XVIII (2000): 25-52.

Bourdieu, Pierre. "Vous avez dit 'populaire'?”. Actes de la recherche en sciences sociales XLVI/46 (1983): 98-105.

Cabrera Infante, Guillermo. Tres tristes tigres. Barcelona: Seix Barral, 1969.

Calderón, Damaris. "Virgilio Piñera: una poética para los años 80". Virgilio Piñera. Teresa Cristófani Barreto, ed. São Paulo: Universidade de São Paulo, 1994. <http:// www.fflch.usp.br.virgilio/ens_calderon.html>. 9 marzo 2009.

Calomarde, Nancy. "Revolución y colonización en el pensamiento crítico sobre Orígenes”. Astrolabio 4. 2007. <http://www.astrolabio.unc.edu.ar/articulos/nuevosfrutos/ articulos/calomarde.php>. 28 mayo 2009.

Calvet, Louis-Jean. Lingüística y colonialismo. 1974. México: Fondo de Cultura Económica, 2005.

Contardi, Sonia. José Martí. La lengua del destierro. Crónica y tradición moderna. Rosario: Universidad Nacional de Rosario, 1995.

“Cuba y el día después, y Vivir y pen(s)ar en Cuba”. Reseña de Vivir y pensar en Cuba. La Habana Elegante, segunda época 19-20. Otoño-invierno 2002. <http://www. habanaelegante.com/Fall-Winter2002/Verbosa.html>. 23 feb. 2009.

Díaz, Duanel. "De la casa del Ser al callejón de las ratas: Diáspora(s) y la 'literatura menor'”. La Habana Elegante (segunda época 18). Verano 2002. <http://www. habanaelegante.com/Summer2002/Verbosa.html>. 26 marzo 2009.

Los límites del origenismo. Madrid: Colibrí, 2005.

Dorta Sánchez, Walfrido. "Estaciones, estados, documentos: panorama de la poesía cubana en los ' 80 y los '90 del siglo XX”. Anales de Literatura Hispanoamericana 31 (2002): 17-38.

Errington, Joseph. “Colonial Linguistics”. Annual Review of Anthropology 30 (2001): 19-39.

Ette, Omar. "Una literatura sin fronteras: Ficciones y fricciones en la literatura cubana”. Cuba: Un siglo de literatura (1902-2002). Anke Birkenmaier y Roberto González Echevarría, coords. Madrid: Colibrí, 2004. 407-31.

"Una literatura sin residencia fija. Insularidad, historia y dinámica sociocultural en la Cuba del siglo XX”. Revista de Indias LXV/235 (2005): 729-54.

Fernández Retamar, Roberto. Calibán. Apuntes sobre la cultura de Nuestra América. 1971. Buenos Aires: La Pléyade, 1973.

“Calibán revisitado”. Todo Calibán. 1986. Buenos Aires: Consejo Latinoamericano de Ciencias Sociales, 2004. 83-94.

“Orígenes como revista”. Thesaurus XLIX/2 (1994): 293-322.

Revista Iberoamericana, Vol. LXXVIII, Núm. 240, Julio-Septiembre 2012, $539-554$
ISSN 0034-9631 (Impreso) 
Figueroa, Sylvia y Néstor Rodríguez. "En la casa de la poesía: encuentro con la escritora Reina María Rodríguez”. Ciberletras9(2003). < http://www.lehman.edu/ciberletras/ v09/figueroarodriguez.html>. 2 junio 2009.

Fornet, Ambrosio. "La diáspora cubana y sus contextos (Glosario)". Casa de las Américas 222 (2001): 22-29.

Fornet, Jorge. Los nuevos paradigmas. Prólogo narrativo al siglo XXI. 2006. La Habana: Letras Cubanas, 2007.

Fowler, Víctor. "Ensayismo, crítica y después”. La letra del escriba 14 (2002). <http:// www.cubaliteraria.cu/revista/laletradelescriba/n14/index.html>. 4 marzo 2009.

"Limones partidos". Cubista Magazine. Verano 2006. < http://cubistamagazine. com/050108.html>. 10 feb. 2009.

"La tarea del poeta y su lenguaje en la poesía cubana reciente". Casa de las Américas 215 (abril-junio 1999): 11-25.

García Borrero, Juan Antonio. “Invitación al choteo”. Casa de las Américas 234 (2004): 75-84.

García Marruz, Fina. La familia de Orígenes. La Habana: Unión, 1997.

Garrandés, Alberto. "Formas del realismo en la ciudad barroca. Diez narradores cubanos de los años 90”. Casa de las Américas 215 (abril-junio 1999): 26-36.

Gilman, Claudia. Entre la pluma y el fusil. Debates y dilemas del escritor revolucionario en América Latina. Buenos Aires: Siglo XXI, 2004.

González-Ripoll Navarro, María Dolores. "Ocio, lecturas y escritura en la ilustración cubana”. Revista de Indias LX/219 (2000): 331-43.

Hernández, Rafael. "Sobre el discurso”. Mirar a Cuba. Ensayos sobre cultura y sociedad civil. 1999. México: Fondo de Cultura Económica, 2002. 165-81.

y Rafael Rojas. Ensayo cubano del siglo XX. México: Fondo de Cultura Económica, 2002.

Hernández Busto, Ernesto. “Un escándalo canónico”. Letras libres 51. Marzo 2003. $<$ http://www.letraslibres.com/index.php?art=8646>. 10 marzo 2009.

“Lezama: la letra y el espíritu”. Cubista magazine. 2004. <http://cubistamagazine. com/a2/020103.html>. 22 mayo 2009.

Jáuregui, Carlos. Canibalia, canibalismo, antropofagia cultural y consumo en América Latina. Madrid: Iberoamericana; Frankfurt: Vervuert, 2008.

Kanzepolsky, Adriana. Un dibujo del mundo: extranjeros en Orígenes. Rosario: Beatriz Viterbo, 2004.

Kozer, José. "Martí, una ansiedad”. Cuba encuentro 3 (1996-97): 62-5.

Lezama Lima, José. "La expresión americana”. El reino de la imagen. 1957. Caracas: Ayacucho, 1981.

Mañach y Robato, Jorge. Indagación del choteo. 1928. La Habana: Libro Cubano, 1955. Mateo Palmer, Margarita. Ella escribía poscrítica. La Habana: Abril, 1995.

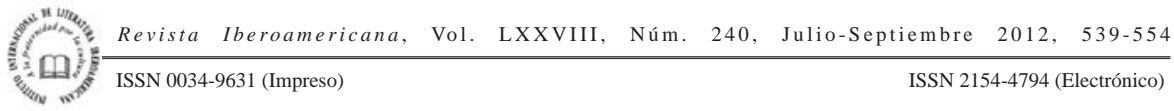


"Las palabras como peces dentro de la cascada: Lezama Lima y el lenguaje”. Casa de las Américas 244 (2006): 21-29.

“Las palabras como peces dentro de la cascada: Lezama Lima y el lenguaje”. La Jiribilla V. 269. Julio 2006. < http://www.lajiribilla.cu/2006/n269_07/269_12. html>. 8 junio 2009.

Morán, Francisco. "Un asiento, y Ponte, entre las ruinas”. La vigilia cubana. Sobre Antonio José Ponte. Teresa Basile, comp. Rosario: Beatriz Viterbo, 2009. 43-71.

Morejón Arnaiz, Idalia. “Eppure si mouve. Las transformaciones de la norma poética en Cuba”. Cuba: poesía, arte y sociedad. Seis ensayos. Manuel Cuesta Morúa, Ivette Fuentes y otros. Madrid: Verbum, 2006. 15-44.

Naranjo Orovio, Consuelo. “Creando imágenes, fabricando historia: Cuba en los inicios del siglo XX”. Historia Mexicana LIII/2 (2003): 511-40.

Nuez, Iván de la. Cuba y el día después. Barcelona: Mondadori, 2001.

Ortiz, Fernando. Nuevo catauro de cubanismos. 1923. La Habana: Editorial de Ciencias Sociales, 1985.

Ortiz García, Carmen. “Cultura popular y construcción nacional: la institucionalización de los estudios de folklore en Cuba”. Revista de Indias LXIII/229 (2003): 695-736.

Pichardo Tapia, Esteban. Diccionario provincial casi razonado de vozesy frases cubanas. 1836. La Habana: Imprenta de M. Soler, 1949.

Ponte, Antonio José. “El abrigo del aire”. 1999. El libro perdido de los origenistas. México: Aldus, 2002. 105-23.

“La lengua de Virgilio”. El libro perdido de los origenistas. 1992. México: Aldus, 2002. 43-52.

Ramos, Julio. “Trópicos de la fundación: poesía y nacionalidad en José Martí”. Paradojas de la letra. Caracas: eXcultura, 1996. 153-64.

Rodríguez Gutiérrez, Milena. "El choteo de la cubanidad. La mirada del otro en la tradición negativa de la poesía cubana”. Encuentro de la cultura cubana 48-49 (primavera-verano 2008): 12-17.

Rojas, Rafael. Motivos de Anteo. Patria y nación en la historia intelectual de Cuba. Madrid: Colibrí, 2008.

Salgado, César Augusto. "Hybridity in New World Baroque Theory.” Journal of American Folklore 112/445 (1999): 316-31.

Salto, Graciela. “La ‘suave risa’ en la crítica cultural: del choteo al camp”. Memorias del silencio: literaturas en el Caribe y Centroamérica. Buenos Aires: Corregidor, 2010. 123-150.

Sánchez Aguilera, Osmar. "Poesía en claro. Cuba, años 80 (long play/variaciones”. Poesía cubana de los 80. A. Llarena y O. Sánchez, eds. Madrid: La Palma, 1993.

Sánchez Mejías, Rolando. “Olvidar Orígenes”. La Habana Elegante segunda época 1 (primavera 1998). < http://www.habanaelegante.com/Spring98/Ecos.htm>. 20 dic. 2008.

\footnotetext{
Revista Iberoamericana, Vol. LXXVIII, Núm. 240, Julio-Septiembre 2012, 539-554 ISSN 0034-9631 (Impreso) ISSN 2154-4794 (Electrónico)
} 
Schieffelin, Bambi B., Kathryn A. Woolard y Paul V. Kroskrity, eds. Language Ideologies. Practice and Theory. Nueva York: Oxford UP, 1998.

Toro, Alfonso de. "Margarita Mateo: posicionalidades y estrategias de hibridación”. Mujeres en el umbral. De la iniciación femenina en las escritoras hispánicas. Emilia Perassi y Susanna Regazzoni, eds. Sevilla: Renacimiento, 2006. 118-48.

Ubieta Gómez, Enrique. Vivir y pensar en Cuba. 16 ensayistas cubanos nacidos con la Revolución reflexionan sobre el destino de su país. La Habana: Centro de Estudios Martianos, 2002.

Uribe, Marcelo. "Introducción”. Orígenes. Revista de Arte y Literatura, La Habana 1944-1956. Edición facsimilar. México: El Equilibrista; Madrid: Turner, 1989.

Vitier, Cintio. Lo cubano en la poesía. 1957. La Habana: Letras Cubanas, 1998.

Weinberg de Magis, Liliana. "La identidad como traducción. Itinerario del Calibán en el ensayo latinoamericano”. Estudios Interdisciplinarios de América Latina yel Caribe 5/1 (enero-junio 1994). <http://www.tau.ac.il/eial/V_1/magis.htm>. 24 feb. 2009.

Zanetti, Susana. “'Es pequeño-es mi vida’... La tensión autobiográfica en Versos sencillos de José Martí”. Leer en América Latina. 1991. Mérida: El Otro el Mismo, 2004. 95-117.

Revista Iberoamericana, Vol. LXXVIII, Núm. 240, Julio-Septiembre 2012, 539-554
ISSN 0034-9631 (Impreso) 